\title{
Pembuatan dan Karakterisasi Kitosan Kulit Udang Galah
}

\author{
Zidni Azizati ${ }^{1}$ \\ 1Jurusan Kimia, Fakultas Sains dan Teknologi, Universitas Islam Negeri Walisongo \\ Semarang-Indonesia \\ E-mail : zidni.azizati@walisongo.ac.id
}

\begin{abstract}
Abstrak
Kitosan merupakan biopolimer yang diturunkan dari kitin, sumber alam yang dapat diperbarui yang sangat berlimpah di dunia setelah selulosa. Kitosan disintesis dari sumber alam yang berasal dari limbah krustasea, ikan, dan kulit udang. Salah satu aplikasi limbah kulit udang yang paling umum yaitu isolasi kitosan. Preparasi kitosan terbagi menjadi tiga tahap. Deproteinasi, dealuminasi, dan deasetilasi. Isolasi kitosan meliputi preparasi limbah kulit udang menjadi kitin dan deasetilasi kitin menjadi kitosan. Kitin dan kitosan dikarakterisasi dengan FTIR dan XRD. Derajat deasetilasi kitosan pada penelitian ini diukur menggunakan FTIR sebesar 93,47\%. Berat molekul kitosan ditentukan dengan viskosimeter kinematik sebesar $19.000 \mathrm{~g} / \mathrm{mol}$. Pola XRD kitosan menunjukkan bahwa struktur kristal kitosan merupakan ortorombik. Hasil analisis dengan FTIR dan XRD menunjukkan bahwa kitosan telah berhasil disintesis pada penelitian ini.
\end{abstract}

Kata Kunci : Kitosan; kulit-udang; derajat deasetilasi

\begin{abstract}
Chitosan is natural biopolymer which is derivated from chitin, the most widespread renewable sources in the world after cellulose. Chitosan was sinthesized from natural resources from waste such crustacean, fish, and shrimp shells. One of the most popular from application of shrimp shell waste was isolation of chitosan. Preparation of chitosan was carried out in three stages, deproteination, dealumination, and deacetylation. Isolation of chitosan including preparation of shrimp shell waste into chitin and deacetylation of chitin to be chitosan. Chitin and Chitosan was characterized with FTIR and XRD. Degree of deacetylation from chitosan in this research which measured by FTIR was 93,47\%. Molecular weight of chitosan which determined by kinematic viscosimetry was $19.000 \mathrm{~g} / \mathrm{mol}$. XRD pattern of chitosan has shown that structur of crystal from chitosan was orthorhombic. Analysize by FTIR and XRD has shown that chitosan in this research was successfully synthesized.
\end{abstract}

Keyword: chitosan; shrimp-shell; degree of deacetylation

\section{Pendahuluan}

Indonesia merupakan negara penghasil udang ketiga di dunia. Komoditas ekspor udang mencapai 69\%. Tahun 2014 produksi udang mengalami peningkatan sebesar 1,62\% (255 ribu ton). Kulit udang selama ini dimanfaatkan sebagai sumber protein dalam ransum pakan ternak atau sebagai sumber prebiotik. Kulit udang mengandung $5-15 \%$ sumber protein dalam ransum pakan ternak dan mengandung 0,52,5\% kitosan sebagai prebiotik (Kumar M. Y., 2017). Peningkatan produksi udang

10 
yang tinggi menyebabkan semakin banyaknya limbah kulit udang yang terproduksi.

Limbah kulit udang biasa secara umum digunakan sebagai bahan campuran dalam pembuatan krupuk, petis, terasi (No, H.K., dkk., 1989). Kulit udang memiliki nilai ekonomis rendah dan diperlakukan sebagai limbah atau dijual untuk pakan ternak binatang (Suchiva, dkk., 2002). Industri peternakan udang menghasilkan limbah kulit udang dalam jumlah yang besar, yaitu mencapai $45-55 \%$ dari berat kotor udang (Lertsutthiwong, dkk., 2002). Limbah kulit udang dapat digunakan untuk memproduksi suatu produk yang memiliki nilai ekonomis lebih tinggi yaitu kitosan (Hossain, dkk., 2014).

Kitosan merupakan polimer karbohidrat alami yang diturunkan dari kitin dan ditemukan dalam jumlah besar pada krustasea, jamur, serangga dan beberapa algae (Hussain, dkk., 2014). Kitosan digunakan dalam aplikasi yang sangat luas, yaitu industri farmasi, biokimia, bioteknologi, kosmetik, biomedis, industri kertas, serta industri tekstil dan makanan (Muzzarelli, 1985). Salah satu cara alternatif yang dapat digunakan untuk meningkatkan kualitas kitosan adalah dengan impregnasi kitosan dengan material lain. Beberapa material yang dapat digunakan untuk memodifikasi kitosan yaitu alumina dan bentonit (Farhana, 2011).

Kitosan dapat dikarakterisasi dengan derajat deasetilasi, berat molekul dan residu protein. Akan tetapi parameter paling penting untuk karakterisasi jenis kitosan adalah derajat deasetilasi (Jana, dkk., 2013). Derajat deasetilasi mempengaruhi sifat fisik, kimia, dan biologi dari kitosan, seperti keasaman dan kebasaan, juga karakteristik elektrostasik, biodegradabilitas, agregasi, sifat penyerapan, dan kemampuan untuk membentuk kelat dengan ion logam. Selain itu, derajat deasetilasi juga menentukan jumlah gugus amino bebas pada polisakarida sehingga dapat membedakan kitin dan kitosan (Li, dkk., 1992).
Kitosan larut dalam asam organik dengan pH sekitar 4-6,5, dan memiliki tingkat kelarutan yang dipengaruhi oleh bobot molekul dan derajat deasetilasi (Mima, dkk., 1983; Edward, dkk., 2016). Harga derajat deasetilasi paling rendah pada kitosan yaitu 40-60\%. Kitosan komersial pada umumnya memiliki harga derajat deasetilasi sebesar 70-90\%. Beberapa aplikasi khusus biologi membutuhkan harga derajat deasetilasi kitosan sebesar $>95 \%$ yang dilakukan dengan metode preparasi dengan biaya tinggi dan juga menghasilkan depolimerisasi sebagian (Tolaimatea, dkk., 2003).

Beberapa metode penentuan derajat deasetilasi kitosan yaitu uji ninhidrin (Curotto dan Aros, 1993), spektroskopi inframerah (Brugnerotto, dkk., 2001), titrasi potensiometri linear (Balazs dan Sipos, 2007), pengukuran enzimatis (Nanjo, dkk., 1991), dan analisis unsur (Shigehiro, dkk., 1981; Gong, dkk., 2003; Gupta dan Jabrail, 2006).

Derajat deasetilasi dikarakterisasi dengan FTIR mengunakan persamaan Domszy dan Robert (1984), yaitu :

$$
\mathrm{DD}=100-\left[\frac{(\mathrm{A} 1651,1) /(\mathrm{A} 3448,7)}{1,33} \times 100\right]
$$

\section{Metode Penelitian}

\section{Alat dan Bahan}

Peralatan yang digunakan dalam penelitian ini adalah peralatan gelas laboratorium, satu set alat refluks, pengaduk magnet, cawan porselen, termometer alkohol, ayakan ukuran 100 (Fischer), blender (Miyako), oven (Fischer, scientific), neraca analitis (AND EK 610i), hot plate, Spektrofotometer Inframerah (Shimadzu Prestige 21), Difraktometer Sinar-X (Shimadzu XRD-6000).

Bahan-bahan yang digunakan dalam penelitian ini meliputi kulit atau cangkang udang galah yang berasal dari desa Godean Yogyakarta, akuades (Lab Kimia Dasar FMIPA UGM), akuabides (Lab Kimia Dasar FMIPA UGM), indikator universal dan kertas saring biasa. Bahan lain yang digunakan 
adalah bahan-bahan dari produk Merck yaitu natrium hidroksida ( $\mathrm{NaOH})$, hidrogen klorida ( $\mathrm{HCl}) 37 \%$, asam asetat $\left(\mathrm{CH}_{3} \mathrm{COOH}\right)$ $100 \%$, asam nitrat $\left(\mathrm{HNO}_{3}\right)$.

\section{Prosedur Kerja}

\section{Isolasi Kitosan}

Cangkang udang dicuci bersih untuk menghilangkan sisa daging dan kotoran yang menempel kemudian dikeringkan dengan bantuan sinar matahari. Cangkang udang yang sudah kering selanjutnya diblender dan diayak menggunakan ayakan berukuran 100 mesh $(150 \mu \mathrm{m})$.

Serbuk cangkang udang yang telah lolos ayakan 100 mesh kemudian dioven pada suhu $60^{\circ} \mathrm{C}$ selama 24 jam. Selanjutnya dilakukan proses isolasi kitosan. Proses isolasi kitosan dibagi dalam tiga tahap yaitu deproteinasi, dealuminasi dan deasetilasi. Langkah pertama yang dilaukan dalam isolasi kitosan yaitu deproteinasi. Pada tahap deproteinasi, dilakukan penimbangan bubuk kitosan yang telah dioven selama 24 jam pada suhu $60^{\circ} \mathrm{C}$ sebanyak 25 gram, selanjutnya bubuk tersebut dimasukkan dalam labu leher tiga $500 \mathrm{~mL}$ dan ditambahkan $250 \mathrm{~mL}$ larutan $\mathrm{NaOH} 4 \%$ (b/b), selanjutnya campuran direfluks pada suhu $80-82^{\circ} \mathrm{C}$ selama 1 jam. Hasil deproteinasi disaring menggunakan kertas saring biasa dan dicuci dengan akuades sampai pH netral. Residu hasil deproteinasi dikeringkan dalam oven dengan temperatur $60^{\circ} \mathrm{C}$ selama 24 jam.

Langkah kedua yaitu demineralisasi. Ditimbang sebanyak 10 gram bubuk cangkang hasil deproteinasi dan dimasukkan ke dalam gelas beker $1000 \mathrm{~mL}$ ditambah $\mathrm{HCl} 1 \mathrm{M}$ sebanyak $150 \mathrm{~mL}$, diaduk dengan pengaduk magnet pada temperatur kamar selama 3 jam. Hasil demineralisasi disaring dan dicuci dengan akuades sampai $\mathrm{pH}$ netral, residu dioven pada suhu $60^{\circ} \mathrm{C}$ selama 24 jam selanjutnya ditumbuk.

Langkah terahir dalam isolasi kitosan yaitu deasetilasi. Sebanyak 10 gram kitin hasil demineralisasi dimasukkan ke dalam labu leher tiga $500 \mathrm{~mL}$ dan ditambahkan $\mathrm{NaOH} 50 \%$ (b/b) sebanyak $150 \mathrm{~mL}$, campuran direfluks pada suhu $100^{\circ} \mathrm{C}$ selama 3 jam. Selanjutnya disaring dengan kertas saring biasa dan dicuci dengan ak uades sampai $\mathrm{pH}$ netral. Residu dioven pada suhu $60^{\circ} \mathrm{C}$ selama 24 jam.

\section{Penentuan derajat deasetilasi kitosan}

Berdasarkan data spektroskopi inframerah maka dapat ditentukan harga derajat deasetilasi. Derajat deasetilasi kitosan dihitung menggunakan dua garis dasar yang berbeda. Garis dasar a diusulkan oleh Domszy dan Robert (1985) dan garis dasar b diusulkan oleh Baxter (1992). Persamaan matematis untuk menghitung kedua garis dasar tersebut yaitu:

$\left.\mathrm{DD}=100-\left[\left(\mathrm{A}_{1655} / \mathrm{A}_{3450}\right) / 1,33\right) \times 100\right] .$. garis dasar $(\mathrm{a})$
$\mathrm{DD}=100-\left[\left(\mathrm{A}_{1655} / \mathrm{A}_{3450}\right) \times 115\right] \ldots \ldots .$. garis dasar $(\mathrm{b})$

Absorbansi pada panjang gelombang gugus amida $\left(1655 \mathrm{~cm}^{-1}\right)$ dan gugus hidroksil $\left(3450 \quad \mathrm{~cm}^{-1}\right)$ dapat dinyatakan oleh persamaan matematika sederhana yang diusulkan oleh Sabnis dan Block (1997) yaitu :

$\log _{10}\left(D_{1} / D E\right)=\left(A_{1655}\right)$ amida...... garis dasar $(a)$
$\log _{10}\left(D_{2} / D E\right)=\left(A_{1655}\right)$ amida...... garis dasar $(b)$
$\log _{10}(A C / A B)=\left(A_{3450}\right)$ hidroksil... garis dasar $(a, b)$

Rasio absorbansi dihitung menggunakan persamaan :

Rasio absorbansi $=$ A1655 (amida) / A3450 (hidroksil)

(Rahayu, 2009).

\section{Penentuan berat molekul kitosan}

Berat molekul kitosan dianalisis di Laboratorium Teknik Kimia Fakultas Teknik UGM menggunakan metode viskosimetri kinematik. Kitosan dilarutkan dalam 0,1 M asam asetat $/ 0,2 \mathrm{M} \mathrm{NaCl}$ dengan variasi konsentrasi 2,5; 5; 7,5 dan 10\% selanjutnya masing-masing larutan kitosan dimasukkan ke dalam viskosimeter, kemudian dihitung waktu yang diperlukan oleh larutan untuk 
mencapai garis batas pengukuran pada alat viskometer.

Viskosimetri merupakan metode untuk menentukan berat molekul. Berat molekul ditentukan melalui hubungan antara [ $\eta$ ] dan berat molekul (Robert dan Domszy, 1982) dalam persamaan MarkHouwink yaitu

$$
[\eta]=\mathrm{Km}(\mathrm{MW})^{\alpha}
$$

\section{Keterangan :}

Km dan $\alpha=$ konstanta Mark Houwink yang tergantung pada jenis polimer,suhu dan pelarut. Cervera, dkk. (2004) mengukur viskositas intrinsik kitosan menggunakan pelarut yang mengandung asam asetat 0,1 $\mathrm{M}$ dan $\mathrm{NaCl}$ 0,2 M. Diperoleh harga $\mathrm{Km}$ sebesar $1,81 \times 10^{-3}$ dan $\alpha=0,93$ (Rahayu, 2009).

\section{Hasil dan Pembahasan}

Pada penelitian ini digunakan cangkang udang sebagai sumber kitin yang selanjutnya akan dideasetilasi menjadi kitosan. Langkah-langkah penelitian untuk mengisolasi kitosan dalam cangkang udang dilakukan melalui deproteinasi, demineralisasi dan deasetilasi.

Deproteinasi dilakukan dengan mereaksikan serbuk cangkang udang dengan larutan $\mathrm{NaOH}$ 4\%. Deproteinasi bertujuan untuk menghilangkan proteinprotein yang terdapat dalam cangkang udang. Cangkang udang mengandung protein sebesar $21 \%$. Tahap demineraliasi serbuk hasil deproteinasi dilakukan dengan menggunakan $\mathrm{HCl} 1 \mathrm{M}$ selama tiga jam dilakukan dengan tujuan untuk menghilangkan mineral-mineral yang terdapat pada cangkang udang. Muzzarelli (1985) melaporkan bahwa cangkang udang mengandung 40-50\% mineral. Menurut Tretenichenko (2006) hewan-hewan crustacean pada umumnya memiliki kandungan mineral yang besar, sedangkan mineral-mineral yang terkandung dalam crustacean tersebut berupa $\mathrm{CaCO}_{3}$ dan $\mathrm{CO}_{3}\left(\mathrm{PO}_{4}\right)_{2}$. Dalam tahap demineralisasi digunakan $\mathrm{HCl}$ karena $\mathrm{HCl}$ merupakan asam kuat, sedangkan mineral-mineral dapat larut dengan asam kuat. Tahap terakhir dalam isolasi kitosan dari cangkang udang yaitu tahap deasetilasi. Tahap deasetilasi dilakukan dengan menggunakan $\mathrm{NaOH}$ $50 \%$. $\quad \mathrm{NaOH}$ digunakan untuk menghidrolisis kitin menjadi kitosan. Pada deasetilasi terjadi pemutusan ikatan antara karbon dengan nitrogen pada gugus asetil kitin tersubstitusi (gugus asetamida) menjadi gugus amina. Adapun mekanisme hidrolisis kitin dengan $\mathrm{NaOH}$ ditunjukkan pada Gambar 1.

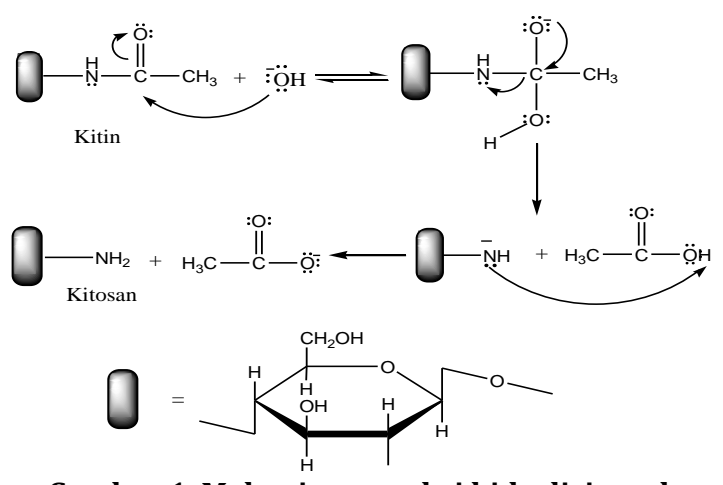

Gambar 1. Mekanisme reaksi hidrolisis pada deasetilasi kitin oleh $\mathrm{NaOH}$ (Champagne, 2002)

Karakterisasi kitin dan kitosan yang dilakukan pada penelitian ini meliputi karakterisasi gugus fungsi pada kitin dan kitosan dengan metode spektroskopi inframerah, karakterisasi kristalinitas kitosan dengan metode difraksi sinar-X (XRD), serta penentuan derajat deasetilasi dan penentuan berat molekul kitosan. Spektra inframerah untuk kitin dan kitosan ditunjukkan pada Gambar 2. Sedangkan interpretasi pita vibrasi gugus fungsional kitin dan kitosan ditunjukkan pada Tabel 1.

Berdasarkan spektra inframerah kitin pada Gambar 2, maka dapat diketahui bahwa spektra inframerah kitin dan kitosan mengalami beberapa perbedaan. Perbedaan spektra kitin dan kitosan ditunjukkan dengan munculnya pita serapan di daerah $1627,92 \mathrm{~cm}^{-1}$ yang merupakan vibrasi ulur $\mathrm{C}=0$ dan pita serapan pada bilangan gelombang 1558,48 $\mathrm{cm}^{-1}$ yang merupakan vibrasi ulur $\mathrm{N}-\mathrm{H}$ asetamida pada spektra inframerah kitin. Kedua spektra tersebut mengindikasikan bahwa kitin telah terbentuk, sedangkan pada spektra 
inframerah kitosan, pita serapa pada bilangan gelombang $1651,07 \mathrm{~cm}^{-1}$ yang merupakan vibrasi ulur $\mathrm{C}=0$ mengalami penurunan intensitas, sedangkan pita serapan untuk vibrasi tekuk $\mathrm{N}-\mathrm{H}$ juga mengalami penurunan intensitas. Hal ini memberikan indikasi bahwa gugus $\mathrm{N}-\mathrm{H}$ amida sekunder yang terdapat pada struktur molekul kitin berkurang akibat lepasnya gugus asetil dan terbentuknya gugus amina $\left(\mathrm{NH}_{2}\right)$ pada kitosan.

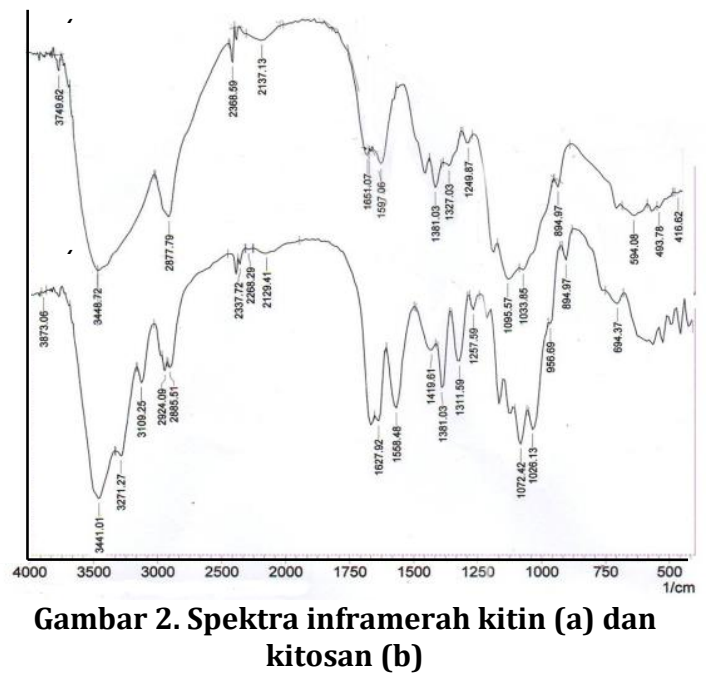

Tabel 1. Interpretasi pita serapan vibrasi gugus fungsional kitin dan kitosan

\begin{tabular}{lcc}
\hline & \multicolumn{2}{c}{\begin{tabular}{c} 
Bilangan \\
\multicolumn{1}{c}{ Interpretasi }
\end{tabular}} \\
\cline { 2 - 3 } & \multicolumn{2}{c}{$\begin{array}{c}\text { Kitin } \\
\text { Kitosan }\end{array}$} \\
\hline $\begin{array}{l}\text { vibrasi ulur O-H } \\
\text { vibrasi ulur C-H }\end{array}$ & 3441,01 & 3448,72 \\
vibrasi ulur C=O (pita & 2885,51 & 2877,79 \\
$\begin{array}{l}\text { amida I) } \\
\text { vibrasi tekuk N-H (pita }\end{array}$ & 1627,92 & 1651,07 \\
$\begin{array}{l}\text { amida II) } \\
\text { vibrasi tekuk C-H, } \\
\text { simetris } \mathrm{CH}_{3}\end{array}$ & 1558,48 & 1597,06 \\
\hline Yanming & 1381,03 & 1381,03 \\
\hline
\end{tabular}

aYanming, dkk. (2001).

Berdasarkan spektra inframerah kitosan maka dapat ditentukan harga derajat deasetilasi kitosan. Perhitungan derajat deasetilasi kitosan dilakukan dengan menggunakan persamaanDomszy dan Robert untuk garis dasar a, dan persamaan Baxter untuk garis dasar b. Berdasarkan garis dasar a (Domszy dan Robert, 1985) didapatkan harga derajat deasetilasi sebesar 76,25\%. Berdasarkan garis dasar b (Baxter, dkk., 1992) didapatkan harga derajat deasetilasi kitosan sebesar 93,47\%, sedangkan kitosan hasil penelitian sebelumnya (Rahayu, 2009) mempunyai harga derajat deasetilasi sebesar 65,31\% berdasarkan garis dasar a dan derajat deasetilasi $84,98 \%$ berdasarkan garis dasar b. Kitosan yang dihasilkan pada penelitian ini memiliki harga derajat deasetilasi yang lebih besar bila dibandingkan dengan kitosan yang didapatkan pada penelitian sebelumnya (Rahayu, 2009). Perhitungan harga berat molekul kitosan dilakukan menggunakan metode viskosimeter kinematik. Berdasarkan penentuan berat molekul kitosan dengan metode viskosimeter kinematik dan perhitungannya maka diperoleh berat molekul kitosan sebesar $19.000 \mathrm{~g} / \mathrm{mol}$.

Pada spektra FTIR kitosan, terdapat puncak serapan pada daerah $3448 \mathrm{~cm}-1$ (vibrasi ulur $\mathrm{N}-\mathrm{H}$ dan $\mathrm{O}-\mathrm{H}$ dari kitosan), 2877 dan $1381 \mathrm{~cm}-1$ (vibrasi ulur C-H), 1658 dan $1324 \mathrm{~cm}-1$ (amida I dan amida III), 1597 cm-1 (vibrasi tekuk NH2 yang kemungkinan overlap dengan amida II), $1157 \mathrm{~cm}-1$ (vibrasi ulur jembatan C-O-C), $1087 \mathrm{~cm}-1$ (vibrasi ulur C-0) (Liu, dkk., 2006). Indikasi terbentuknya kitosan adalah berkurangnya gugus asetil yang ditandai berkurangnya intensitas puncak serapan pada bilangan gelombang $1658 \mathrm{~cm}-1$ (vibrasi C=0) dan $1558 \mathrm{~cm}-1$ (vibrasi ulur N-H asetalamida), dimana pada spektra kitin intensitasnya masih tajam. Adapun derajat deasetilasi kitosan dihitung dari persamaan Baxter dan diperoleh sebesar 93,23\% sehingga kitosan yang diperoleh dalam penelitian tergolong pada kelas food grade.

Karakterisasi kandungan mineral dalam kitosan diperkuat dengan data difraktogram sinar X. Difraktogram kitosan ditunjukkan pada Gambar 3. Berdasarkan Gambar 3 dapat diketahui munculnya puncak pada sudut difraksi $19,94^{\circ}$ yang bersesuaian dengan data yang didapatkan oleh Muzarelli (1997). Pada difratogram kitosan hanya muncul 2 puncak utama yaitu pada sudut difraksi $19,94^{\circ}$ dan sudut difraksi $10,15^{\circ}$. Tidak munculnya puncak-

14 
puncak pada sudut difraksi $29,5^{\circ} ; 23,17^{\circ}$; $36,06^{\circ}, 39,5^{\circ} ; 43,74 \circ ; 48,6^{\circ} ; 49,06^{\circ}$ yang merupakan puncak-puncak yang karakteristik untuk mineral $\mathrm{CaCO}_{3}$ sesuai dengan data hasil penelitian yang telah dilaporkan oleh Muzarelli (1997) menunjukkan bahwa perlakuan pada cangkang udang menjadi kitosan telah menyebabkan mineral-mineral tersebut berkurang atau hilang.

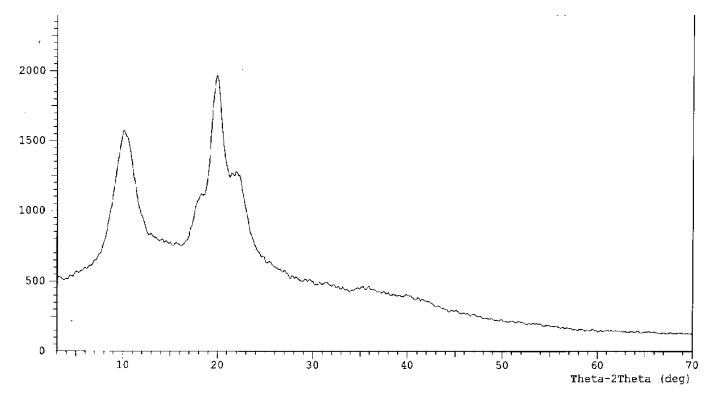

Gambar 3. Difraktogram sinar-X kitosan

Dari hasil analisis XRD, terlihat bahwa kitosan memiliki struktur kristalin dengan puncak utama pada $19.94^{\circ}\left(\mathrm{d}_{100}\right)$, sehingga dapat diperkirakan adalah ortorombik dengan sel satuan $\mathrm{a}=4,4 \AA, \mathrm{b}=10,0 \AA$, dan $c=10,30 \AA$ (Tian, dkk., 2004). Kitosan terbukti sudah tidak mengandung mineralmineral seperti CaCO3, yang memiliki puncak-puncak pada $2 \theta$ sekitar $26,20^{\circ}$, $29,50^{\circ}, 36,06^{0}, 39,5^{0}, 43,740,48,60^{\circ}$, dan 49,060. Hasil analisis FTIR dan XRD membuktikan bahwa kitosan telah berhasil diisolasi dari kulit udang.

\section{Simpulan}

Kitosan dari kulit udang telah berhasil disintesis melalui metode deproteinasi, demineralisasi dan deasetilasi. Analisis dengan FTIR menunjukkan bahwa terjadi penurunan intensitas puncak pada bilangan gelombang $1658 \mathrm{~cm}^{-1}$ (gugus fungsi $\mathrm{C}=0$ ) dan $1558 \mathrm{~cm}^{-1}$ (gugus fungsi $\mathrm{N}-\mathrm{H}$ ) yang menunjukkan bahwa kitosan telah berhasil disintesis dari deasetilasi kitin. Derajat deasetilasi kitosan ditentukan dengan persamaan Baxter sebesar 93,47\% dan berat molekul kitosan diukur menggunakan metode viskosimeter kinematik sebesar $19.000 \mathrm{~g} / \mathrm{mol}$.

\section{Daftar Pustaka}

Balázs, N., dan Sipos, P., 2007, Limitations of $\mathrm{pH}$-potentiometric titration for the determination of the degree of deacetylation of chitosan, Carbohydrate Research, 342 (1), 124130.

Baxter, A., Dillon, M., dan Taylor, K.D.A., 1992, Improved method for i.r. determination of the degree of $\mathrm{N}$ acetylation of chitosan, International Journal of Biological Macromolecules, 14 (3), 166-169.

Brugnerotto, J., Lizardi, J., Goycoolea, F. M., dan Argüelles-Monal, W., 2001, Desbrières, J., Rinaudo, M. An infrared investigation in relation with chitin and chitosan characterization, Polymer, 42 (8), 3569-3580.

Champagne, L. M., 2002, The synthesis of water soluble n-acyl chitosan derivatives for characterization as antibacterial agents, Dissertation, B.S. Xavier University of Louisiana.

Curotto, E., dan Aros, F., 1993, Quantitative Determination of Chitosan and the Percentage of Free Amino Groups, Analytical Biochemistry, 211 (2), 240241.

Domszy, J.G. dan Robert, G.A.F., Evaluation of infrared spectroscopic technique for analyzing chitosan, Journal of Macromoleculer: Science- Pure Applied Chemistry, vol. 8, pp. 1671-1677, 1984.

Edward, J.D., Marni K., dan Riardi P.D., 2016, Isolasi Kitin dan Kitosan dari Limbah Kulit Udang, Majalah BIAM, 12 (01): 32-38.

Farhana,N., 2011, Chitosan-Bentonite Composite for the Removal of Tartrazine, Malachite Green and Copper (II) from Aqueous Solution, Thesis, Universiti Sains Malaysia.

Gong, M., Dang, Y., Wang, Y-B., Yang, S., Winnikde, F. M., dan Gong, Y-K., 2013, Cell membrane mimetic films immobilized by synergistic grafting and crosslinking, Soft Matter, 9 (17), 4501-4508. 
Gupta, K. C., dan Jabrail, F. H., 2006, Effects of degree of deacetylation and crosslinking on physical characteristics, swelling and release behavior of chitosan microspheres, Carbohydrate Polymers, 66 (1), 43-54.

Hossain, M.S., dan Iqbal, A., 2014, Production and Characterization of Chitosan from Shrimp Waste, J. Bangladesh Agril. Univ., 12 (1): 153160.

Hussain, M.R., Murshid I., dan Tarun K. M., 2014, Determination of Degree of Deacetylation of Chitosan and their Effect on the Release Behaviour of Essential Oil from Chitosan and Chitosan-Gelatin Complex Microcapsules, Rev. Tec. Ing. Univ. Zulia., Vol. 37 (2), 69-77.

Jana, S., Saha, A., Nayak, A.K., Sen, K.K., dan Basu, S.K., 2013, Aceclofenac-loaded chitosan-tamarind seed polysaccharide interpenetrating polymeric network microparticles, Colloids and Surfaces B: Biointerfaces, 105 (1), 303-309.

Kumar, M.Y., dan Ravi, A., 2017, Extraction and Characterization of Chitosan from Shrimp Waste for Application in the Feed Industry, International Journal of Science, Environment and Technology, Vol. 6, No 4: 2548-2557.

Lertsutthiwong, P., How, N.C., Chandrkrachang, S. dan Stevens, W.F., 2002, Effect of Chemical Treatment on the Characteristics of Shrimp Chitosan, Journal of Metals, Materials and Mineral, 12(1):11-18.

Li, Q., Dunn, E. T., Grandmaison, E. W., dan Goosen, M.F. A., 1992, Applications and properties of chitosan, Journal of Bioactive and Compatible Polymers, 7 (4), 370-397.

Mima, S., Miya, M., Iwamoto, R. dan Yoshikawa, 1983, Highly Deacetylated Chitosan and Its Properties, J. Appl. Polym. Sci., 28 (6): 1909-1917.

Muzarelli, R.A.A., dan Peter, M.G., 1997, Chitosan Handbook, New York: European Chitin Society.
Muzzarelly, 1985, Studies on The Suitable of Chitinocistic Microorganism for Shrimp Waste Fermentation, Dissertation, University of Washington, New York.

Nanjo, F, Katsumi, R., dan Sakai, K., 1991, Enzymatic method for determination of the degree of deacetylation of chitosan, Analytical Biochemistry, 193 (2), 164-167.

No, H.K., dan Meyers, S.P., 1995, Preparation and characcterization of chitin and chitosan-a review, Journal Aqua Food Prod Technol, 42(2):27-52.

Rahayu, E., 2009, Pengaruh Konsentrasi Kitosan pada Pembuatan Komposit Kitosan-Lempung, Skripsi, FMIPA, UGM, Yogyakarta.

Sabnis, S., dan Block, L.H., 1997, Improved infrared spectroscopic method for the analysis of degree of $\mathrm{N}$-deacetylation of chitosan, Polymer Bulletin, 39 (1), 67-71.

Shigehiro, H., Shigeru, T., dan Yotaro, K., 1981, Heterogeneous distribution of amino groups in partially $\mathrm{N}$ acetylated derivatives of chitosan, Agricultural and Biological Chemistry, 45 (6), 1335-1339.

Suchiva K., Chandrkrachang S., Methacanon P. dan Peter M.G., 2002, Proceedings of the 5th Asia Pacific Chitin and Chitosan Symposium \& Exhibition, Bangkok, Thailand.

Tolaimatea, A., Desbrieresb, J., Rhazia, M., dan Alaguic, A., 2003, Contribution to the preparation of chitins and chitosans with controlled physicochemical properties, Polymer, 44 (26), 7939-7952.

Tretenichenko, E.M., Datsun, V.M., Ignatyuk, L.N. dan Nud'ga, L.A., 2006, Preparation and Properties of Chitin and Chitosan with Controlled PhysicoChemical Properties, Polym, 44, 79397952.

Wang, L. dan Wang, A., 2007, Adsorption Characteritisc of Congo Red onto the Chitosan/Montmorillonit Nanocomposite. Journal of Hazardous Materials, 147: 979985. 